A. Chumak, S. Klimenko, S. Klimenko, A. Manokhin, A. Naydenko, M. Kopeikina, V. Burikin, Kyiv, Ukraine, M. Bondarenko, Cherkasy, Ukraine, V. Burlakov, Mariupol, Ukraine

\title{
FINISH MACHINING OF THE CUTTING INSERTS FROM CUBIC BORINE NITRIDE BL GROUP COMPOSITE
}

\begin{abstract}
Finishing methods of machining of superhard composite's working elements based on cubic boron nitride BL group are considered. The results of the microgeometry formation research of the cutting inserts' surfaces during machining by free powders of synthetic diamond, grinding wheels and a method of vibro-magnetic-abrasive machining (VMAM) are presented. It is shown that during VMAM the friction between the inserts' surfaces and the abrasive particles result in microremoval of the material, which reduces the roughness of the cutting inserts' surfaces. It is established that additional fine grinding with 14/10 mkm synthetic diamond powder provides the absence of microgeometry defects of the cutting inserts' surfaces left by pre-machining. The result of high-quality rounding of cutting edges and the formation of surfaces of cutting inserts with less roughness is an increase in strength and wear resistance of metal-cutting tools in high-speed machining under conditions of significant loads.

Keywords: diamond machining; vibro-magnetic-abrasive machining; cutting inserts; CBN; surface roughness; friction forces.
\end{abstract}

\section{INTRODUCTION}

The development of modern mechanical engineering is associated with the creation and implementation of new materials and advanced technological processes of their machining. The unique properties of polycrystalline composites based on cubic boron nitride (CBN) allow their use in various fields of technology, including cutting tools, loaded parts of machines, devices, electronic equipment. Due to the high level of hardness of the products formation from such composites it is possible only with the use of technologies that use tools made of synthetic diamonds. Improving the superhard composites machining is associated with the study of the regularity of a complex multifactorial grinding process. At the same time, a significant limitation of machining efficiency is insufficient scientific substantiation of its finishing processes - grinding, finishing, polishing, conditions of lubricants and coolants application in conjunction with the strength and performance characteristics of the machined surface of the products [1].

One of the main reasons for failure of cutting CBN inserts is chipping of cutting edges, which is caused by exceeding the allowable values of stresses in the wedge of the tool $[2,3]$. The studies show that rounding the cutting edges on tools of any material can significantly (from 2 to 8 times) increase the stability and

(C) A. Chumak, S. Klimenko, S. Klimenko, A. Manokhin, A. Naydenko, M. Kopeikina, V. Burikin, M. Bondarenko, V. Burlakov, 2021 
reliability of tools, improve the quality of products machined surfaces [4]. At present, diamond-abrasive machining technologies - grinding, finishing, vibro abrasive machining - are used to form replaceable multifaceted cutting inserts with given geometric parameters [5].

In vibro abrasive machining, the formation of the surfaces of the machined product is carried out by simultaneous chipping, abrasion and microcutting of the allowance fragments. The working tool in this process is an abrasive mix, which includes abrasive powder (with the addition of synthetic diamond powder) and abrasive granules. The components of the mix move under the influence of vibrations in the working chamber of the device. Chipping occurs when single peaks of grains from the abrasive mix collide with the product, abrasion occurs at relative mutual, almost parallel, movement of the product and elements of the abrasive mix, microcutting is accompanied by removal of the thinnest layers of material from the product surfaces. In addition, the vibro-abrasive machining is characterized by the impact stress on the workpiece, which can increase the defect of the machined surfaces.

To improve the productivity of the machining process and the quality of the machined surface is possible by using into the working area components that will add more elastic component to the working, such as replacing abrasive powder in the mix with ferromagnetic abrasive powder and applying a magnetic field to the machining area [6]. In this case, the magnetic field is used as a bond of the abrasive environment, and the vibration provides a gradual movement of the workpiece together with the abrasive granules through this environment, providing the forming process. Thus, the machining will take place with less intense chipping and the impact stress, but with more intensive abrasive machining and microcutting of the allowance. Machined surfaces of products, especially of brittle materials, such as CBN $B L$ group, after such machining do not have microcracks and streaks which are characteristic to the conventional methods of abrasive machining.

Synthetic diamond particles will be contained in the irregularities of the abrasive granules and between the particles of ferromagnetic powder, and thus will be able to participate in the machining process, increasing its productivity.

Given the above, a new method of finishing abrasive machining-vibromagnetic abrasive machining (VMAM), which involves abrasive removal of the allowance in the presence of a magnetic field with relative movement of abrasive grains and machined products due to forced vibrations in the machining area [7]. Machining is performed using various abrasive mixes, which include abrasive powders (synthetic diamond powders), alumina granules, ferromagnetic abrasive powders.

VMAM allows to form and control the surface roughness of composite products that have high mechanical properties and are non-magnetic, such as 
cutting inserts with $\mathrm{CBN}$, while increasing the productivity of finishing and the ability to form some special areas, such as rounding radii of cutting edges.

Magnetic abrasive powder is located between the poles of the electromagnet, forming an elastic environment. Thus, the magnetic field, creating elastic columns of single grains of ferromagnetic abrasive powder, acts as a bond of the tool. The elasticity degree of this bond is regulated by the change in magnetic field strength according to the different stages of machining. Thus, VMAM can approach grinding with free or bound abrasive, allowing you to take advantage of the first or second type of machining in one work cycle.

The movement of the workpieces relative to the columns of the magnetic abrasive tool is created by the vibration of the equipment working chamber, which houses the workpieces and the abrasive mix.

The goal of the presented work is to study the roughness of the surfaces of CBN $B L$ group cutting inserts after additional machining by low-grain diamond powder based tools and vibro-magnetic-abrasive machining.

\section{RESEARCH METHODS}

The planes grinding of CBN cutting inserts was performed by powders of synthetic diamond «AC6»160/125, 80/63, «ACM» 40/28, 28/20, 14/10 on cast iron grinders. The machining of inserts' back surfaces was performed by grinding wheels $1 \mathrm{~A} 1300 \times 126 \times 40 \times 5$ AC6 $80 / 63-4$ B2-01 and $1 \mathrm{~A} 1300 \times 126 \times 40 \times 5$ «CM» 40 / 28-4 B2-01.

A special device [8] was made for performing experimental work with VMAM (Fig. 1).

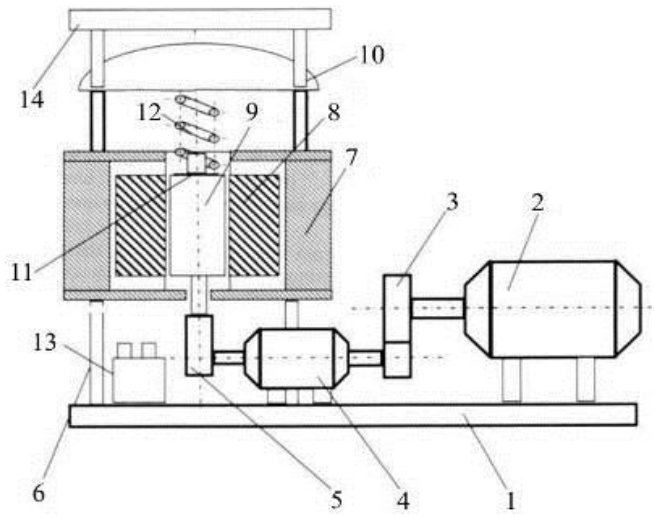

Figure 1 - The VMAM device scheme 
The base of the device is the frame 1 , on which the electric motor KD-50 is mounted ( $n=2780 \mathrm{rpm}, 50 \mathrm{~W}$ ) 2, lowering gear (oscillation frequency $\sim 25 \mathrm{~Hz}$ ) 3 , bearing unit 4 , which is the support of the shaft of the eccentric vibratory drive (oscillations amplitude $4 \mathrm{~mm}$ ) 5 . On the racks 6 above the vibratory drive is a housing 7 with a stator 8 of a three-phase electric motor that creates a magnetic field. In the housing, in the inner space of the stator, there is a working chamber 9 for workpieces and abrasive mix. A cap 10 is fixed above the container and the stator. A spring 12 is inserted between the cap and the container cover 11 , which provides the vibration of the working chamber. Power supply is carried out through the input circuit breakers 13 . Above the cap is a fan 14 to cool the stator.

Given the high mechanical characteristics of CBN, the process of cutting inserts machining takes place in a container made of silicon carbide $\mathrm{SiC}$, which provides its high wear resistance and eliminates the possibility of shielding the magnetic field. As the components of the abrasive mix $\left(125 \mathrm{~mm}^{3}\right)$ were used electrocorundum granules $\mathrm{A}_{2} \mathrm{O}_{3}$, «AC6» 28/20 synthetic diamond powder (in the amount of $15 \%$ of the total volume of the mix) and the «Feromap» ferromagnetic powder 200/100. 10 inserts were machined simultaneously. The processing time was $40 ; 120 ; 180 ; 360 \mathrm{~min}$. The amount of removed material was estimated by weighing the inserts after the machining.

The CBN cutting inserts RNMN 070300 (CBN BL group 45-55\%, TiC) were used as machined inserts.

The study of the microrelief of the CBN inserts surfaces was performed using the atomic-force microscope NT-206, which allowed to obtain microroughnesses profilograms, surfaces topograms and distribution of conditional (lateral) frictional forces (between the atomic-force microscope indenter and the studied surface) on the surface area $S_{\text {nom }}=169 \mathrm{mkm}^{2}$. Analysis of microroughness profiles allowed to establish the arithmetic average $(R a)$ and statistical average $(R q)$ values of the of the microroughness profile ordinates deviation on the workpieces surface from the average line, as well as the maximum height of profile irregularities (Rmax), total surface area $\left(S_{\text {fact }}\right)$ and surface evolution coefficient $k= \pm S_{\text {nom }} / S_{\text {fact }}$. The absolute estimates error was: $\pm 0.002 \mathrm{mkm}$.

Parameters of roughness and mechanical stresses of the machined surfaces measurement was performed at control points (area of $13 \times 13 \mathrm{mkm}$ ) on the surface of the workpiece using also profilograph-profilometer SurfTest SJ-201. According to the distribution of lateral forces along the surface of the workpiece, which indirectly (in nominal units) allows to establish the distribution of friction forces $\sigma$. 
Workpieces were pressed into plastic materials such as aluminum or copper wire and then the imprint was analyzed with an optical microscope to determine the cutting edge radius of the CBN inserts after VMAM.

\section{RESEARCH RESULTS}

According to the technical conditions for CBN cutting tools, the working surface roughness parameter $R a$ should not exceed: front surface $-0.16 \mathrm{mkm}$, rear surface $-0.20 \mathrm{mkm}$, support surface $-0.40 \mathrm{mkm}$.

Based on the abovementioned, the processes of forming high-quality working surfaces of CBN cutting inserts should be given special attention to additional finishing.

Additional finishing of CBN $B L$ group cutting inserts was performed by working surfaces grinding on front and back planes by powder of synthetic diamond «ACM»14/10. The results of topographic studies and lateral friction forces for the CBN insert's unpolished surface are given in a Table 1. The scanning results, topographic studies and lateral friction forces for the CBN insert's polished surface are shown in Fig. 3, Table 2.

Table 1 - The topographic parameter values of the CBN insert's unpolished surface

\begin{tabular}{|c|c|c|c|}
\hline A point number & $R a, \mathrm{~nm}$ & $R q, \mathrm{~nm}$ & $\sigma$, c.u. \\
\hline 1 & 388 & 509 & 1200 \\
\hline 2 & 275 & 336 & 5550 \\
\hline 3 & 326 & 396 & 8800 \\
\hline 4 & 393 & 460 & 9100 \\
\hline
\end{tabular}

Table 2 - The topographic parameter values of the CBN insert's polished surface

\begin{tabular}{|c|c|c|c|}
\hline A point number & $R a, \mathrm{~nm}$ & $R q, \mathrm{~nm}$ & $\sigma$, c.u. \\
\hline 1 & 255 & 294 & 2000 \\
\hline 2 & 232 & 257 & 2880 \\
\hline 3 & 210 & 243 & 2000 \\
\hline 4 & 209 & 254 & 5500 \\
\hline 5 & 317 & 367 & 2160 \\
\hline 6 & 264 & 367 & 4100 \\
\hline
\end{tabular}

Table 3 - The topographic parameters values of the CBN insert's rear surface

\begin{tabular}{|c|c|c|c|}
\hline A point number & $R a, \mathrm{~nm}$ & $R q, \mathrm{~nm}$ & $\sigma$, c.u. \\
\hline 1 & 41 & 62 & 2100 \\
\hline 2 & 141 & 162 & 9200 \\
\hline 3 & 80 & 95 & 8500 \\
\hline 4 & 75 & 94 & 2500 \\
\hline
\end{tabular}




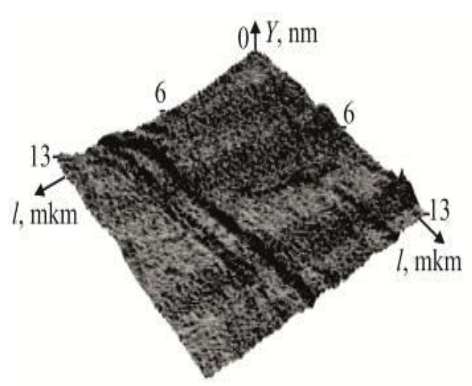

$a$

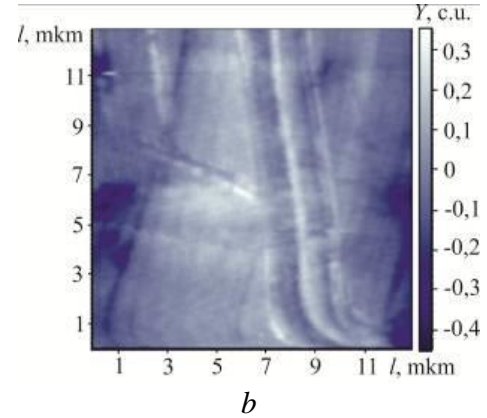

$b$

Figure 2 - The results of scanning the polished $C B N$ insert's profile: $a$ - area's surface 3D image; $b$ - distribution of lateral friction forces

The study of topography on the rear surface and lateral friction forces at the control points of polished cutting inserts was also researched (Fig. 3, Table 3).
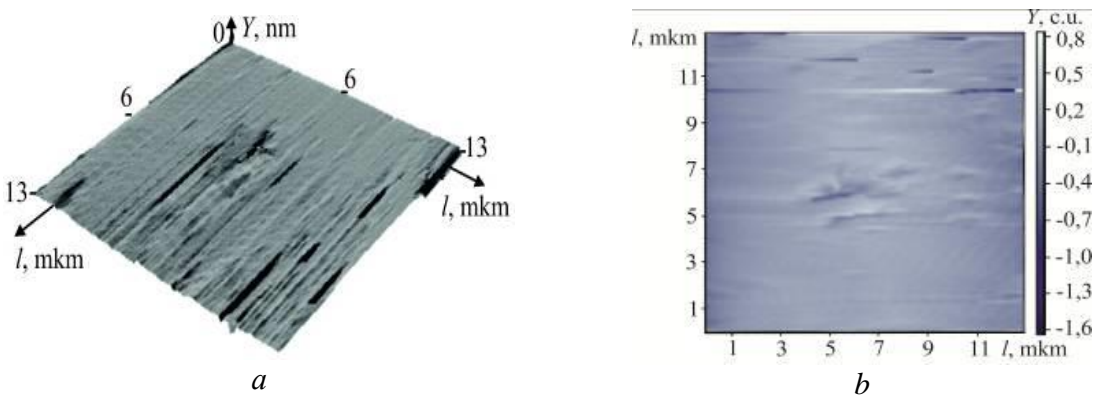

Figure 3 - The topographic research of the rear surface's cutting insert: $a$ - area's surface 3D image; $b$ - distribution of lateral friction forces

Analyzing the available data, it can be noted that for both unpolished and polished CBN $B L$ group cutting inserts, areas with different roughness and appearance of micro-irregularities and, accordingly, with different degrees of friction force distribution are characteristic. It is determined that the value of microroughnesses for the polished surface is in the range $R a 209-317 \mathrm{~nm}, R q 243-$ $367 \mathrm{~nm}$. The distribution of conditional friction forces on the inserts' surface is in the range: 2000-5500 c.u. for polished base and 1200-9100 c.u. for unpolished base. 
3D images of the cutting plate surface (Fig. 2,a) after grinding by synthetic diamond powder «AC6» $160 / 125$ on the surface were analyzed. It is possible to note the presence of individual material breaks, grinding lines, dents and craters of different shapes and sizes. At the control points (Fig. 2,a) the topography of the surface is represented by sharp grinding lines, which indicates the instability of the machining process, which is due to the diamond powder particles heterogeneity in size and strength. The existence of such defects does not have a significant effect on the friction force distribution on the insert's surface (Fig. 2, $b$ ), which is due to the small size of the defects.

Surface defects have a slightly different appearance, namely the appearance of craters with a smooth surface and smooth transitions, which is due to the action of temperatures in the contact area of the machined surface and the grinding tool. Such defects have a significant area and affect the friction distribution on the insert's surface.

When using a tool with CBN cutting inserts, especially at high cutting speeds, the presence of such defects on working surfaces can significantly affect its stability, as in such areas the stresses can be localized, sufficient to generate microcracks and other microdefects that contribute to the cutting inserts' destruction.

The topography of the surface of the cutting inserts after additional grinding has a different look. It is mainly represented by the remnants of the grinding lines, the surface is devoid of sharp peaks, and the grinding lines themselves have the form of small depressions with smooth transitions. In some areas of the inserts it was possible to obtain surfaces on which defects in the form of craters are completely absent.

Additional grinding of cutting inserts' surfaces with "ACM" 14/10 synthetic diamond powder allows to improve the friction force distribution. Additional finishing of the inserts on the back surface with a diamond wheel with "ACM" $14 / 10$ diamond powder allowed to significantly reduce the surface roughness but not its defectiveness (Fig. 4, a). The topography of the surface is mainly represented by craters of significant depth (Fig. 4, $b$ ). A possible explanation for this nature of the change in the rear surface topography is the imperfect technology of polishing, especially for the radial cutting inserts.

VMAM of cutting inserts was performed after their machining by diamond grinding. It should be noted that after diamond machining on the surface may appear some defects in the form of grooves, the removal of which with VMAM is impossible.

In the profilogram (Fig. $4, a)$ a roughness $(R a 0.250)$ of the cutting inserts' surface after grinding was shown (Table 4). On the machined surface there are no sharp transitions between depressions and peaks, and last ones are dominated (Fig. $4, b)$. The machined surface is smooth and has no abnormal defects. 

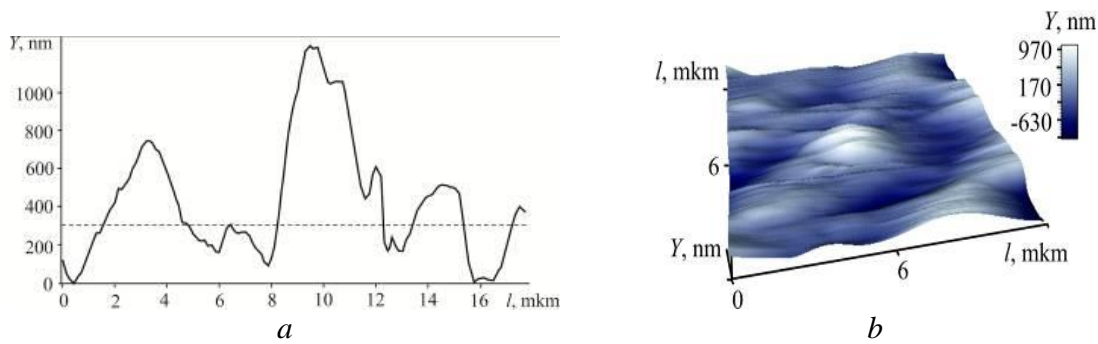

Figure 4 - The profilogram $(a)$ and the surface area's 3D image $(b)$ of the cutting insert after diamond grinding

Table 4 - Parameters of roughness of the machined surfaces of the CBN's cutting inserts

\begin{tabular}{|l|c|c|c|c|}
\hline \multirow{2}{*}{$\begin{array}{c}\text { Method and time of } \\
\text { machining }\end{array}$} & \multicolumn{4}{|c|}{ Values of surface parameters } \\
\cline { 2 - 5 } & $R a, \mathrm{mkm}$ & $R q, \mathrm{mkm}$ & $S, \mathrm{mkm}^{2}$ & $k$ \\
\hline Grinding & 0.250 & 0.302 & 0.168 & - \\
\hline VMAM 40 min & 0.225 & 0.303 & 0.181 & 0.933 \\
\hline VMAM 120 min & 0.204 & 0.253 & 0.181 & 0.994 \\
\hline VMAM 180 min & 0.197 & 0.253 & 0.170 & 0.994 \\
\hline VMAM 360 min & 0.195 & 0.232 & 0.172 & 0.982 \\
\hline
\end{tabular}

In Fig. 5 the relief of the surface and the distribution of the lateral friction forces' average values (Fig. 5, $b$ ) were shown. Lighter fragments correspond to a greater value of the force.
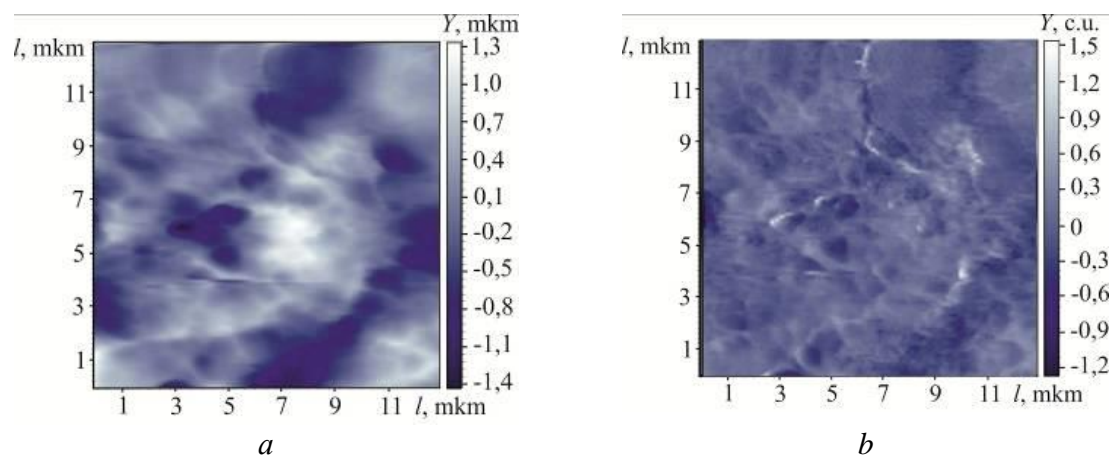

Figure 5 - The relief $(a)$ and distribution of conditional friction forces on the insert's surface $(b)$ after diamond grinding

The distribution of the conditional friction forces' values (Fig. 5, b) on the insert's surface processed with diamond grinding indicates that there are some 
defects with increased friction resistance compared to the average values on the surface (white dots and spots). These defects are caused by the presence on the surface of irregularities that exceed the average values or the adhesion of other materials that accidentally hit the surface of the plate. The presence of such defects allows us to conclude that the coefficient of friction at the micro level is not constant and in the process of using cutting inserts may vary depending on which part of its surface is in contact with chips at the moment.

In the first 40 minutes of VMAM is the most intensive removal of the allowance material from the cutting insert, accompanied by changing the roughness of the machined surface (Fig. 6, $a, b$, table. 4).
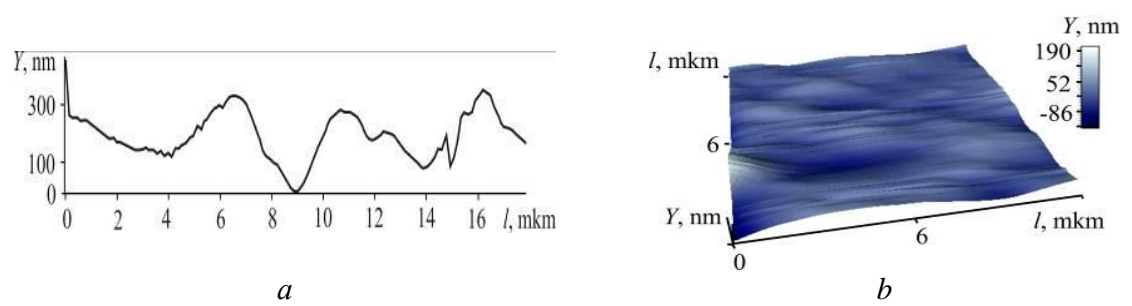

Figure 6 - The profilogram surface $(a)$ and the area's 3D image $(b)$ of the cutting insert after 40 min of VMAM

The analysis of the obtained results shows that the VMAM process most intensively affects the vertices of microroughnesses, reducing their height parameters. It can be concluded that according to the decreasing of the surface evolution coefficient $k$ depressions are predominant.

The distribution of the conditional friction forces' values (Fig. 7,b) on the cutting insert's surface after 40 min of VMAM indicates that there are almost no surface defects, as well as sharp transitions between depressions and peaks of microroughnesses. The peaks of the micro-irregularities are devoid of sharp peaks and have a flat character.

After 120 minutes of VMAM the machined surface is characterized by the roughness' decreasing (Table 4). And there is a balance of values between the height of the peaks and the depth of the depressions of the microroughness on the machined surface, as evident by the value of the surface evolution coefficient $k$, which is close to one.

On the further evolution of the surface state after VMAM for 120 min can be judged by the image of the relief and the distribution of conditional friction forces on the machined surface (Fig. 8). As a result of machining the surface with smooth transitions between peaks and depressions and with the minimum number of defective zones with the increased degree of resistance to friction is formed. 

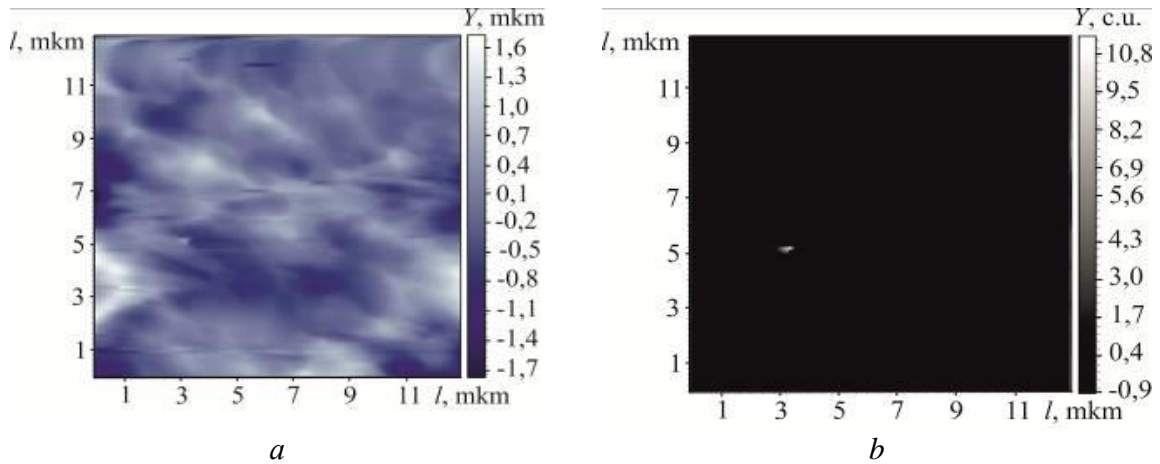

Figure 7 - Relief $(a)$ and distribution of conditional friction forces on the insert's surface $(b)$ after 40 min of VMAM
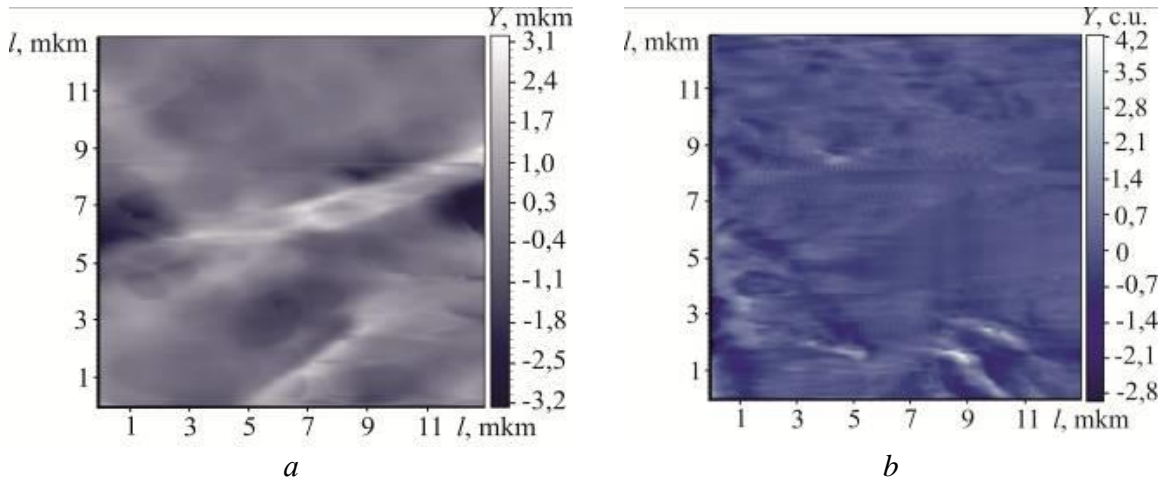

Figure 8 - Relief ( $a$ ) and distribution of conditional friction forces on the insert's surface $(b)$ after 120 min of VMAM

The further processing for 180 and $360 \mathrm{~min}$. does not have a significant effect on the roughness of the machined surface (Table 4), which is associated with the destruction of the abrasive grains of the abrasive mix and reduce their cutting ability. It is advisable to renew the abrasive mix every 120 minutes to achieve a more intense change in the inserts' surface roughness.

The microroughnesses' height on the machined surface and the magnitude of the radius of the CBN insert's cutting edge curvature change asymptotically during machining (Fig. 9, a).

The roughness of the machined surface of the CBN cutting inserts was decreased as a result of VMAM. The shape of the relief corresponded to the relief 
of the surface during the fatigue breaking, which leads to the removal of separate CBN's particles, as well as smoothing of separate grooves left during premachining. The fatigue breaking of the material in the machining area at VMAM occurs under the action of cyclic alternating loads, which are perceived by local areas of the machined surface when interacting with the components of the abrasive mix.

The fatigue mechanism of destruction at VMAM is realized in two stages: $1^{\text {st }}$ - gradual accumulation of defects in a surface layer of the machined insert without visible destruction of the material; $2^{\text {nd }}$ - after reaching a certain concentration of microdamages in the surface layer of the machined insert; there is a rapid destruction with the wear particles formation.
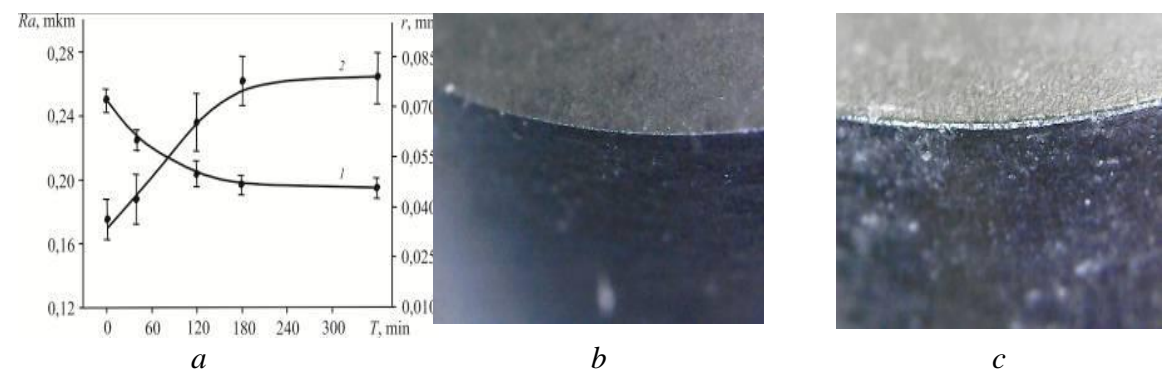

Figure 9 - The dependence of the microroughnesses' height of the machined surface (1) and the radius of the cutting edge (2) of the CBN cutting insert on the VMAM time $(a)$, the cutting edge before finishing $(b)$ and after 240 min of VMAM (c)

Rounding of edges $(r)$ for the CBN cutting inserts is one of the main factors for increase of durability of tools at high-speed machining, and also at impact machining. During VMAM, the cutting inserts are most intensively machined in the area where the surfaces of the inserts are connected, which is due to their lower geometric strength, as well as the higher frequency of micro-impacts of the abrasive particles of the mix on the edge rather than on flat surfaces. Machining time and components of an abrasive mix depend on surface's initial roughness during VMAM. It is possible to receive the cutting edges radius $r$ from 10 to 50 microns. The cutting edge after VMAM has the correct geometric shape along the entire length with a smooth junction of front and rear surfaces (Fig. 9, $b, c$ ).

Based on the dependence presented in Fig. 10, $a$, the kinetics of rounding the edges of the CBN cutting inserts can be divided into three stages depending on the processing time: $-1^{\text {st }}$ stage (0-40 min.) has a slight change in the cutting edge radius, as the fatigue breaking is the main mechanism, which is characterized by the presence of a certain time during which the surface layer of the cutting insert 
increases the concentration of defects under the action of the abrasive environment to a certain critical level, after which the material is removed; $-2^{\text {nd }}$ stage $(40-180$ min.) characterized by an intensive removal of the material and, as a consequence, an increase in the cutting edge radius due to the high concentration of surface defects; - at $3^{\text {rd }}$ stage (180-360 min.) the radius of the edge almost does not change, which means that the process of material removal during VMAM at this time interval practically does not occur because the abrasive mix is no longer able to press a significant impact load on the machined surface due to great wear of abrasive particles, as well as the strengthening of the insert's surface layer as a result of machining.

Due to the cutting edges rounding, increased rounding of the tops of cutting inserts, reduced roughness of the insert's surfaces, the use of VMAM increases the strength and wear resistance of turning and milling tools which are operating in hard load conditions - discontinuous cutting, medium and large feeds, uneven allowance.

\section{SUMMARY}

The additional grinding of the surfaces of the CBN $B L$ group cutting inserts by the powder of synthetic diamond "ACM" $14 / 10$ provides the reduction of the lateral wear force on the insert's working surfaces (2000-5500 c.u. for grinding surfaces and 1200-9100 c.u. for a finished surface). Also a change in the topography of the surface occurs - there are no defects like the sharp peaks and craters, which appeared after previous machining in connection with which the wear force distribution has much more uniform character.

VMAM of the CBN $B L$ group cutting inserts is an effective finishing operation. The abrasive environment is clinging to the insert's surfaces during the machining in the magnetic field, and due to the vibration effect, the process of friction between the inserts' surfaces and the abrasive environment, resulting in micro-removal of the material, which reduces the roughness of the machined surfaces of the cutting inserts. The cutting edges' radius size of the CBN inserts can be controlled by changing the parameters of VMAM in accordance with the conditions of further operation of tools with such cutting inserts.

The cutting edge after VMAM has the correct geometrical form along entire length with smooth junction of front and rear surfaces.

References: 1. Instrumenty iz sverkhtverdykh materialov / pod red. N.V. Novikova, S. A. Klimenko. Moscow: Mashinostroyeniye, 2014. - 608 p. 2. V.O. Trilisskiy, G.S. Bol'shakov, A.V. Lipov, Ye. N. Yarmolenko. Finishnaya obrabotka smennykh mnogogrannykh plastin s tsentral'nymi otverstiyami. Izvestiya VUZ. Povolzhskiy region. Tekhnicheskiye nauki. - 2010. - № 2 (14). pp. 131-137. 3. Burykin, V.V. Obrabotka detaley tortsevoy frezoy, osnashchennoy polikristallicheskimi sverkhtverdymi materialami. Inzheneriya poverkhnosti i renovatsiya izdeliy: mat. mezhdunarod. nauch.tekhn. konf., 20-24.05.2019, g. Svalyava. - Kyiv: ATMU, 2019. - pp. 25-29. 
4. A. S. Manokhin, S. A. Klimenko, S. An. Klimenko, V. M. Beresnev. Perspektivnyye tipy pokrytiy dlya instrumentov, osnashchennykh polikristallicheskim KNB. Nadtverdí materíali. - 2018. - № 6. - pp. 7888. 5. V.M. Gakh. Vibroabrazivnaya obrabotka tverdosplavnogo instrumenta. Kramatorsk: DGMA, 2009. - 220 p. 6. L.M. Akulovich, L.Ye. Sergeyev. Tekhnologiya i oborudovaniye magnitno-abrazivnoy obrabotki metallicheskikh poverkhnostey razlichnogo profilya. - Minsk: BGATU, 2013. - 372 p. 7. S.An. Klimenko, A.O. Chumak. Víbro-magnítna-abrazivna obrobka rízal'nikh plastin íz PKNB. Nadtverdí, kompozitsíyní materíali ta pokrittya: otrimannya, vlastivostí, zastosuvannya: tezi mízhnarod. nauk.-tekhn. konf., 28-29.05.2020, m. Kyiv: ÍNM NAN Ukraïni, 2020. - pp. 7-8. 8. S. A. Klimenko, V. Í. Burlakov, Yu. Ye. Rizhov ta ín. Patent Ukraïni na korisnu model' № 143357. Sposíb obrobki bagatogrannikh plastin z nadtverdoï keramíki // Byul. «Promislova vlasníst'». - 2020. № 14.

\title{
Анатолій Чумак, Сергій Клименко, Сергій Клименко, Андрій Манохін, Андрій Найденко, Марина Копєйкіна, Віталій Бурикін, Київ, Україна, Максим Бондаренко, Черкаси, Україна, Віктор Бурлаков, Маріуполь, Україна
}

\section{ФІНІШНА ОБРОБКА РІЗАЛЬНИХ ПЛАСТИН 3 КОМПОЗИТУ НА ОСНОВІ КУБІЧНОГО НІТРИДУ БОРУ ГРУПИ ВL}

\begin{abstract}
Анотація. Розглянуті фінішні методи обробки робочих елементів з надтвердого композиту на основі кубічного нітриду бору групи BL (CBN(45-55 об.\%)-ТiC). Наведені результати досліджень формування мікрогеометрії поверхні різальних пластин при обробиі вільними порочками синтетичного алмазу, иліфувальними кругами та методом вібро-магнітноабразивної обробки (ВМАО). Розроблено схему та сконструйовано пристрій для практичної реалізації процесу ВМАО різальних пластин, щчо включає контейнер для оброблюваних пластин, вібраційну систему i пристрій для створення електромагнітного поля. Встановлено, що додаткове тонке шліфування поверхонь різальних пластин порошком синтетичного алмазу АСМ 14/10 дозволяє покращити розподіл латеральних сил тертя по робочих поверхнях пластин та при забезпечує відсутність дефектів у вигляді гострих вершин та кратерів, залишених попередньою обробкою. Показано, щчо в прочесі обробки ВМАО різальних пластин, завдяки магнітному полю та вібраційному впливу здійснюється процес тертя між поверхнями пластин та абразивним середовищем, в наслідок чого відбувається мікровидалення матеріалу, щуо веде до зменшення шорсткості оброблених поверхонь пластин та забезпечує потрібне заокруглення різальної кромки, яка має правильну геометричну форму по всій довжині з плавним сполученням передньої та задньої поверхонь. Результатом якісного заокруглення різальних кромок та формування поверхонь різальних пластин з меншою шорсткістю є підвищення мічності та зносостійкісті металорізального інструменту при високошвидкісній обробці деталей в умовах значних термобаричних навантажень.
\end{abstract}

Ключові слова: алмазна обробка; вібро-магнітно-абразивна обробка; різальні пластини; CBN; шорсткість поверхні; сили тертя. 